\title{
EU interest representation or US-style lobbying?
}

\author{
GREENWOOD, J. and YOUNG, A.R.
}

2005

This original publication GREENWOOD, J. and YOUNG, A.R. 2005. EU interest representation or US-style lobbying? In Jabko, N. and Parsons, C. (eds.) With US or against US? European trends in American perspective. The state of the European Union, 7. Oxford: Oxford University Press, chapter 12, is reproduced by permission of Oxford University Press https://doi.org/10.1093/0199283958.003.0012 


\section{EU Interest Representation or US-Style Lobbying?}

\section{Justin Greenwood \& Alasdair R. Young}

Particularly since the launch of the single European market programme in the mid1980s, there has been an explosion of interest groups competing for influence at the European level. More recently, there have been explicit efforts to engage these interest groups in the policy process in an effort to bolster the democratic legitimacy of European Union (EU) rules. The policy process, however, is usually described as strikingly apolitical. Although there are winners and losers from the policy outputs, the policy process itself remains largely consensual, and thus its politics are often difficult to see.

This chapter charts and seeks to explain the development and character of EU interest group politics. It argues that the development of EU interest group politics has been shaped by the interaction of two key causal mechanisms for change: 'the impact of institutional legacies' and the 'defence and extension of democracy.' The initial surge in interest group participation was principally a consequence (legacy) of the transfer of authority to the EU and of greater policy activity in the wake of the single market programme. The subsequent efforts to integrate interest groups more fully into the policy process reflect an effort to extend democracy.

Institutional legacies, however, also limit the extent to which the efforts to extend European democracy will be successful. EU authority remains relatively restricted in scope, which means that, although the number and variety of interest groups present at the EU level have increased dramatically over the past 20 years, EU civil society is not nearly as developed as it is in the mature democracies of western Europe or in the United States. The importance of the policy areas that remain under member-state control and the member-states' role in the EU policy process further mean that the vast majority of interest groups will not transfer their focus entirely to the (federal) EU level.

Furthermore, four institutional legacies help to explain the apparently apolitical character of EU interest group engagement. One legacy is that the EU's primary business is regulation, which does not bring winners and losers into conflict as explicitly as do distributive politics. Although the costs (or benefits) of a regulation may be clear and significant to some actors, the benefits (or costs) tend to be opaque or diffuse for most actors. Moreoever, regulations are often highly technical, which both makes them relatively inaccessible and privileges expertise and information. The second legacy is the tradition of diplomatic decision-making within a highly institutionalised framework, which means that compromise is highly prized. The third is the relatively weak tradition of pluralist politics within many of the member-states. In member-states with strong corporatist traditions, compromise is the language of politics. In those with statist traditions, interest groups are unused to wielding influence. The fourth institutional legacy, which may be changing, is that a particularly confrontational interest group tactic-litigationhas been restricted for EU interest groups. These four legacies reinforce each other and create the apparently apolitical character of EU interest group competition.

In order to cast the development of EU interest group politics into sharper relief, we examine them with reference to the development of interest group politics in the United States. There are two principal reasons for doing so. First, the US is often held-up as the archetypal interest group society-the pinnacle of pluralism as a source of democratic legitimacy. Second, the EU is often seen as more open to interest groups than most of its member-states and thus, in this regard, as more similar to the United States. Although we think that this superficial similarity 
distracts from a number of important differences between the EU and US, it provides a useful foil for our analysis.

This chapter begins by sketching the proliferation of European interest groups since the 1980s and examining the impact of the institutional legacy of the single European market programme and of the efforts to extend democracy on this process. We shall also explore how other institutional legacies limit the extent to which the increase in the number and variety of interest groups can actually extend democracy. We then turn to our other puzzle-the strangely apolitical character of EU interest group politics. In addition, in the light of the preceding analysis, we will examine the character of transatlantic interest group relations. We conclude be re-engaging with the prospects for extending democracy in the EU through interest group participation.

Before turning to the substance of our argument, it is worth noting that there is relatively little literature that has sought to compare interest group organisation, mobilisation and strategies in the EU and US. There are, in fact, relatively few studies that compare interest groups in different countries more generally. 1 The most relevant of these studies for our purposes is Coleman and Montpetit's (2000) study of the organisation of business interests in multi-tiered and centralised (national) systems. They argue that whether firms organize nationally or regionally (and then form national associations) depends on how they perceive their market. Firms that are focused on national or international markets are unlikely to organize at the level of smaller territorial subdivisions. Coleman and Montpetit argue that political and constitutional structures also affect how firms organize, but that these structures may be industry specific. Baumgartner's (1996) study of French and US public interest groups also stresses the importance of the political institutional context for explaining the organisation and influence of interest groups. The argument advanced in this chapter is broadly consistent with these arguments.

\section{Interest Representation in the European Union}

Interest representation in the EU has recently undergone two significant developments. The first was a bottom-up increase in the number of interest groups operating at the EU level. The second has been a top-down effort to engage a variety of interest groups more extensively in EU policy-making. The first development is an institutional legacy of the single European market programme. The second is an attempt to extend democracy.

The 'institutional legacy' of the single European market

The increase in the importance of the European level of governance associated with the relaunch of the integration project attracted more groups to Brussels. This increase was a response not simply to the range and quantity of sectors and products affected by the single European market programme (Young and Wallace, 2000a). The speed with which legislation was being developed created pressures for permanent representation in Brussels. Further, the reinvigoration of qualified majority voting meant that national interests could not rely on 'their' government to defend their interests, building alliances with likeminded firms, associations and governments became necessary, and being in Brussels made that easier.

This increase in interest group activity was most pronounced among business interests, which were most directly affected by the regulatory focus of the single

\footnotetext{
${ }^{1}$ Some exceptions include Thomas (2001) on relations between groups and parties in liberal democracies; Baumgartner (1996), who compares public interest groups in France and the US; and Schmitter and Streeck (1981) and Coleman and Montpetit (2000), who look at the organisation of business interests.
} 
European market (Coen 1997; Greenwood 1997; Schmidt 1999). Subsequently, however, non producer interests, particularly consumer and environmental groups, began to shift their activities to Brussels and/or restructure their activities in order to counter the perceived dominance of business interests and as the policy agendas-particularly environmental and consumer protection-'flanking' the single European market developed (Webster 1998; Young 1998).

In some respects, these developments parallel those in the United States. Both the New Deal and the surge of regulatory activity in the 1970s increased the importance of the Federal level, and encouraged the formation of national trade associations to inject business interests into the policy process (Berry 1984; Lowi and Ginsberg 2000). A significant difference from the EU experience, however, is that in the 1970s US business groups were responding to an upsurge in consumer and environmental regulation, rather than consumer and environmental groups responding to an increase in legislative changes perceived to be pro-business.

A second difference is that although the number of interest groups operating at the EU level has risen rapidly and has reached an impressive level, it is dwarfed by the number of interest groups operating in the US (see Table 1).

Table 1 Overview of interest representation in the EU and US (number)

\begin{tabular}{|l|c|c|}
\hline \multicolumn{1}{|c|}{ Type of association } & EU & US \\
\hline EU/Federal interest groups & 1450 & est. $7,333^{2}$ \\
\hline Law firms/public affairs consultancies & 268 & 5,536 \\
\hline
\end{tabular}

Sources: Greenwood 2003; personal correspondence with the Public Records Office, US Senate, 17 June 2003 (figures as of 30 September 2002).

The reinvigoration of the European integration project may also be having an impact on the form, as well as the scale, of interest representation in Europe. Coleman and Montpetit (2000) suggest that as European integration progresses firms and other interests will begin to organize primarily at the EU level as they come to see it the principal locus for relevant policy. There are some limited signs of this. Around sixteen per cent of EU business associations are exclusively direct member associations of individual (large) companies (Greenwood 2002), in line with Coleman and Montpetit's expectation. In addition, twenty-six per cent accept individual firms as members along side the more traditional associational members (Greenwood 2002). Further, the 1990s saw an increase in direct lobbying of EU institutions by individual firms (Cowles 2001; Coen and Grant 2001). The development of business-EU relations has meant that national industry associations have had to adapt, changing their relationships with their national governments and strengthening their engagement in the EU policy process (Cowles 2001).

The extension of democracy: From the White Paper to the Constitutional Treaty The second significant development in EU interest group politics has been the active promotion of civil society engagement in the EU policy process. In a quite conscious way, organized civil society players have been built in to the development of EU democratic mechanisms. The European Commission has for some time deliberately built up the landscape of citizen interest groups so as to provide Madisonian style checks and balances in the EU political system, both upon EU political institutions and as mutual watchdogs among civil society organisations. The Commission channels around $€ 1000$ million of funding each year through civil society

\footnotetext{
2 According to the 2000 edition of the Encyclopaedia of Associations, there were 22,000 non-profit membership organisations that are national in scope. It is, however, estimated that only one-third of these devote resources to political activities (Grossman and Helpman, 2001).
} 
organisations (Commission, 2000). Further, for the past decade, the EU's agenda has been pre-occupied with the debate about a 'democratic deficit' of the EU, arising from lukewarm public endorsement (or rejection) of EU Treaties in member-state referendums (see 'the defence and extension of democracy' discussion in the introductory chapter). This new 'policy frame' (Baumgartner and Jones, 1993) is highly pervasive and has profoundly changed the nature of EU policy-making. Faultlines in EU representative democracy, such as the absence of majoritarian politics to bring 'politics to the people,' has laid emphasis upon supplementary participatory mechanisms of democratic development, some of which carry deliberative overtones.

The Commission, in particular, has good reasons for being accessible to all comers. In part this is because it needs policy-making partners as agents to carry its quest for more European integration to the member-states. Interest groups provide invaluable technical support for policy-making. The Commission is a notoriously under-resourced organisation for the range and size of functions it undertakes, with around 6,000 policy-making officials. The Commission also actively solicits diverse interests in order to bolster the legitimacy of its policy proposals (Streeck and Schmitter 1991; Schmidt 1999). The Commission therefore has a determined policy not to erect barriers preventing access to it by interest organisations. It has thus consistently rejected the type of formal scheme of accrediting groups that can be found with other transnational organisations such as the Council of Europe and the United Nations. As a result, the Commission is a very open, increasingly transparent, policy-making institution. This transparency has been nurtured in a quite deliberate way by the Commission, so as to equip interest groups with the ability to exercise accountability in the EU political system. Thus a document register on Europa enables enquirers to obtain access to virtually any document (including third party documents) within fifteen days of requesting it, while open web based consultations enable civil society players to see who is saying what to whom.

Initially business groups were the principal interlocutors because they could provide the information necessary for decision-making and the acquiescence that would facilitate implementation. Subsequently, however, there has been an unfolding agenda that promises to a broader range of civil society groups more participation in return for enhancements in their capacities and transparency. The driving concerns behind these initiatives are to 'connect' with EU civil society, and is now the most predominant EU policy frame. These factors have resulted in a warm climate for public interests and their representative organisations to operate in, and resonate with the openness of access to policy-making found in the United States. Tony Long, Director of the Brussels European Policy Office of the World Wide Fund for Nature since 1989, recently reflected that

'all the talk in Brussels these days about the role of 'civil society' and the need to consult more widely is not just words... whatever the reason, civil society is becoming recognised as the missing element' (Davis 2003: 66).

Initiatives such as the 1995 'Citizens First!' campaign based around a public information drive were followed with major programmes aimed at ensuring the transparency of EU policy-making and devices to interact directly with citizens. The turn of the millennium saw the White Paper on Governance, aimed directly at addressing the remoteness that many citizens feel from the EU. The agenda unfolding from the 2001 White Paper is changing the relationship between the EU institutions and interest groups in a number of ways that make it even harder for any one interest to routinely dominate the policy process. In particular, the White Paper encourages open consultations through documents placed on the internet. 
Voluntary accountability by the Commission in demonstrating how it responded to the input it receives also demonstrates the extent to which the Commission has pursued input (participatory) legitimacy.

The efforts to extend democracy through engaging civil society are also reflected in the Constitutional Treaty that was signed in October 2004. It contains provisions on representative (Art. I-46) and participatory democracy (Art. I-47), with the latter containing explicit recognition of the role of civil society organisations organized at the EU level, and a mechanism to enable individual citizens to participate directly in EU policy-making (see Box 1).

\section{Box 1 Article I-47 The principle of participatory democracy}

1. The institutions shall, by appropriate means, give citizens and representative associations the opportunity to make known and publicly exchange their views in all areas of Union action.

2. The institutions shall maintain an open, transparent and regular dialogue with representative associations and civil society.

3. The Commission shall carry out broad consultations with parties concerned in order to ensure that the Union's actions are coherent and transparent.

4. Not less than one million citizens who are nationals of a significant number of Member-states may take the initiative of inviting the Commission, within the framework of its powers, to submit any appropriate proposal on matters where citizens consider that a legal act of the Union is required for the purpose of implementing the Constitution. European laws shall determine the provisions for the procedures and conditions required for such a citizens' initiative, including the minimum number of Member-states from which such citizens must come.

Outside the explicit agenda of extending democracy, a May 2002 decision by the European Court of First Instance may further open up the EU's policy process by agenda setting the ability of representative organisations to have the right to initiate litigation (Reid 2003). The present position is that only an entity directly affected by a particular measure, such as an individual or a company, may bring a complaint to the European courts, thus preventing interest groups taking up causes. Public interest groups seeking a change in the law therefore have to seek individual plaintiffs with a good case willing to let their name go forward (Harlow and Rawlings 1992). If interest groups become able to challenge legislation, as happened in the US in the 1960 s and 1970 s, resorting to the courts is likely to become more common, as is the case in the US.

The EU's emphasis on consulting civil society echoes, and in some cases surpasses, the steps taken by the US federal government to ensure that interest groups have access to administrative decision-making procedures (Berry 1984). Thus in both the EU and US organized civil society acts as a mechanism of participatory legitimacy in policy-making. In the EU, as in the US, 'lobbying' has become a major, legitimate channel of democratic politics (Berry 1984).

Without EU-wide political parties, the adversarial and majoritarian politics of presidential elections and elections that change 'government,' and an EU wide media, however, there are few other conveyor belts to take EU politics to its citizens. This places considerable pressure upon organized civil society to act as two way channels of communication and socialisation. As elite organisationsmostly associations of national associations-however, they have severe limitations in undertaking this role, as we shall discuss below. Nonetheless, there are few 
alternatives, and in these circumstances the EU institutions have sought to work with them.

The impact of EU structures on interest representation and influence

Concerns about interest group politics as a source of participatory legitimacy focus on the danger that broader participation does not automatically guard against the undue influence of particular interests (Berry 1984). The EU's efforts to extend democracy, however, reinforce a number of characteristics of the EU's political system that work against particular interests routinely dominating the policy process. First and foremost, this is because of the fragmentation of EU decisionmaking between supranational institutions, and between supranational institutions and member-states. As policy-making shifts venues, so new rules of the game apply. The technocratic nature of policy-making in the Commission, where policy is formulated, makes it a natural focus for interest groups. Yet even if a 'done deal' is reached in the technocratic Commission, most policy-making procedures channel measures through to European Parliament, with its democratic credentials often making it lean towards public interests, and from there to the Council of Ministers. As the latter two institutions search interactively for a common agreement, the complexities of finding compromise increasingly exclude outside interests. These factors can be cleverly used by the Commission to insulate itself from pressure by pointing out to outside interests the need to propose something which stands a chance of finding agreement in other decision-making institutions (Grande 1996).

Furthermore, the pluralist character of the plethora of interests engaged in the EU policy process is augmented by the contending interests even within interest groups that stem from different national policy contexts (Young and Wallace 2000b). In combination with the Commission's openness, this means that the EU tends to be more open to 'outsider' interest groups than are the member-state governments. The relationship between the Commission and interest groups, however, tends to be closer than in the US. The Commission sponsors the core activities of a significant number of groups-some sixty per cent of public interest groups in the mid-1990s (Aspinwall and Greenwood 1998). In addition, it has an extensive network of advisory committees with established interest group members (Streeck and Schmitter 1991; Webster 1998; Young 1998). In contrast, there is a much more pronounced separation between interest groups and government in the US (Baumgartner 1996). This difference has complicated cooperation between EU and US public interest groups (see below).

Although the Commission is generally open to contending interests, there are 'islands of quasi-corporatism' in which particular Directorates General have particularly close and exclusive relationships (Greenwood, Grote and Ronit 1992). The relationship between the Directorate General for Employment and the European Trade Union Confederation is also extremely close, with some (Martin and Ross 2001) charging that the latter has become too dependent upon the former to achieve its goals.

While organized interests help to bring in resources such as expertise and information, these can overload the system together with the political demands they bring. For instance, a 2003 Commission proposal for a regulatory chemicals Directive so as to place upon companies the burden of proof for product safety, resulted in some 6,500 separate responses to a consultation exercise. Both business and environmental lobbies were highly active but each has declared itself dissatisfied with the outcome, a feature that might be expected in highly pluralistic policy domains. Consequently, there is some concern that the search for input legitimacy might interfere with output (winning by results) legitimacy. 
Forms of EU interest representation and limits to the extension of democracy There are two particularly striking characteristics of the approximately $1500 \mathrm{EU}$ interest organisations, which have implications for the ability of an increase in EU level interest group activity to deliver a real extension of participatory democracy. First, EU interest groups tend to concentrate in relatively few policy areas and are often highly specialised, with quite technical concerns. Second, they tend to be associations of (national) associations.

The EU's most highly developed areas of policy authority are with regard to agriculture, trade and the single European market. This is a narrower policy remit that in traditional states. The EU has only a marginal role in key areas such as health care, welfare provision, moral issues (such as abortion), and national security. EU level interest groups, although beginning to branch out across the policy spectrum, naturally tend to reflect this policy focus. As a consequence, some of the largest and most influential lobbying groups in the US, such as the AARP (formerly the American Association of Retired People) and the National Rifle Association, are concerned with issues that are outside the EU's policy purview. As the EU does not seem to deal extensively with issues that directly and consciously affect people's lives, EU interest groups do not attract broad, direct popular support.

In addition, the overwhelming regulatory focus of EU policy process tends to encourage highly specialised interest groups. As the most visible costs or benefits of regulations tend to affect only narrow groups of actors, there are a great many very highly specialised interest groups operating at the EU level. There are, for example, six separate trade associations representing aspects of the glass industry. The high degree of specialisation in representation, therefore, may overstate the political significance of the number of EU interest groups, particularly that of business interests. Again, specialisation works against engaging (even indirectly) broad publics in the EU's policy process.

Further, because the EU is a new political system built on top of existing national systems, interests in the EU tend to organize in associations of national associations. This has several implications for the potential of increasing engagement with EU interest groups to extend democracy. Although the framework of an association of associations provides for legitimacy through breadth, it also creates problems of effectiveness and representativeness. Such associations often have trouble reaching agreements among their members, which means they are unable to provide the Commission with the EU-wide perspective that it wants. In addition, such associations may be remote from their membership constituency. Some EU interest organisations-particularly public interest groups-have little interest in engaging their members in EU public affairs, and spend little time doing so (Warleigh 2001). They are elite players, sucked into the institutionalised world of Brussels politics, in which the transaction costs of mass membership activism are prohibitive. In response to this, the Commission's White Paper calls for European interest groups to improve their internal transparency and accountability:

'with better involvement comes greater responsibility...civil society organisations need to tighten up their internal structures, furnish guarantees of openness and representativity, and prove their capacity to relay information or lead debates in their member-states' (European Commission 2001: 15-17).

\section{Examples of EU interest organisations}

The preceding discussion is illustrated by the following brief overview of some of the major or illustrative interest groups active at the EU level. 
The principal general EU business associations are: UNICE, a confederation of national employer and industry associations; the European Round Table of Industrialists (ERT), modelled on the US Business Round Table, a selective 'by invite only' organisation comprising the CEOs of some of Europe's largest companies; the EU Committee of the American Chamber of Commerce (AMCHAM$\mathrm{EU})$, the 'voice of American business in Europe'; UEAPME, a confederation of national small business associations; and EUROCHAMBRES, representing national associations of Chambers of Commerce. These organisations have contrasting strengths and weaknesses. Breadth is a source of strength and weakness to the confederations, while ERT and AMCHAM-EU enjoy the benefits and weaknesses of representing a selective constituency of, respectively, European and American large firms.

The high reputations of these latter two organisations principally derive from their novelty and impact at the time of their formation in the early 1980 s, when the EU agenda was dominated by wealth creation questions and when a forward marching Commission was on the look out for key allies with fresh ideas. As with all organisations, this momentum has been difficult to sustain. Both continue to enjoy a reputation of bringing fresh thinking to policy-making, being quick off the mark, and helping to set agendas, but each has developed its own problems (see Greenwood 2003), and experienced a modest recent haemorrhaging of members.

AMCHAM-EU has been successful in curbing the worst excesses of brash and aggressive American lobbying which were evident from the late 1970s to the early 1990s over issues such as the Vredling Directive, the second Banking Directive (Cowles 1997), and the first Tobacco Advertising Directive. Around one third of the estimated 350 large firms visibly active in EU public affairs are American, and AMCHAM-EU has helped to socialise them in the ways of 'European lobbying.' This culture is substantially more low key, polite and subtle, as companies such as Philip Morris came to appreciate to their cost.

These general business associations are joined by almost 1,000 EU level trade associations. As with all political systems, where there are shared interests between their members and common sectoral features, they work well. But there are a number of features about the EU environment which limit their influence, in addition to the structural factors discussed above. The EU is not a state, and therefore the Commission has a limited ability to 'licence' associations as monopoly policy partners to the extent that can be found in corporatist European countries. Without this source of coherence, associations have to turn to micro specialism as an organizing device. Whilst the effect in an individual association can be that of coherence, the overall system effect can be one of competing associations across the product chain. And the openness of the Commission to all-comers, together with the general fragmentation of EU decision making, means that trade association members can and do by-pass their representative associations in engaging directly with political decision making. There is a substantial dialogue between the Commission and individual large companies, and in some parts of the Commission there is a preference for talking directly with large firms rather than trade associations, because of the grass roots experiences and fleetness of foot they bring to policy-making.

Further structural weaknesses affecting EU business associations include their specialisation upon political representation. They either represent national associations, or large firms, neither of whom require their European association to provide them with business services. This means that many of them have few resources and are highly dependent upon membership subscriptions, rather than their own income streams. They can be over controlled by their members and be 
restricted to articulating the short term demands of their members, rather than having the ability to lead their members perceptions of what their interests are on particular issues.

Many public interest groups also take the form of associations of associations. These groups tend not to have the same problems of conflicting interests, although priorities do differ. Some do face resource problems because of the relative poverty of their member associations, although some others have become substantial organisations in excess of twenty staff, in some cases with a high degree of Commission funding. Because they are not as specialised as the business associations they may have more member and therefore more absolute resources than some business associations, but they are responsible for covering a much broader range of policy.

Frequently the Commission 'pump primes' an activity which lies on the fringes of EU policy competencies by funding the foundation of public interest groups. The Commission then nurtures them through designation of official functions, such as 'observatory' status to supply it with information. This pattern is most clearly observed in the relationship between the Commission's Directorate General Employment and Social Affairs and public interests. Although not all relationships between Commission DGs and organized interests are this close, they all have features arising from mutual dependencies. Some relationships are mature, highly regulated, and driven by commitment at Commissioner level, such as those between development NGOs and DG Development. There is now a general tendency within the Commission for dialogue with 'families' of cognate public interest groups. Thus, the 'Contact Group of Civil Society' brings together cognate families of environmental groups (the 'G8'), human rights groups, world development groups, and the 'Social Platform,' 39 leading organisations in the social policy field. These are evidence of maturity in the 'NGO' sector. Some analysts have seen in the external trade sector traces of deliberative democracy, with groups contributing significantly to policy frames and development through self managed and highly organized dialogue structures (Goehring 2002).

In some circumstances an interest group may even become a demand constituency for European integration. The European Women's Lobby, for example, has been credited with the acquisition of new Treaty competencies (Helfferich and Kolb 2001) in ways foreseen by neo-functionalist theory. It also has involved its members in 'campaigns,' such as in the run-up to the Treaty of Amsterdam, to explain to European women what was on offer from European integration. By undertaking these tasks, very strong relationships can arise between public interest groups, and the patron in the Commission. Where there are also funding dependencies, a few can become 'extensions' of the Commission.

\section{The apolitical character of EU interest group politics}

Having examined the contours of EU interest group politics, we turn our attention to a puzzle that is particularly striking in contrast to the US; the relatively apolitical charater of EU interest group competition. We contend that four institutional legacies account for this relatively apolitical form of politics.

The first institutional legacy is that the EU's business is overwhelmingly about regulation and the character of that activity tends to diffuse political competition. Although regulatory politics is usually understood to provoke interest group competition (Lowi 1964), a crucial issue in the mobilization of contending interest groups is the anticipated distribution of costs and benefits from the proposed legislation (Wilson 1980). If the benefits (or costs) of a proposal are diffuse or opaque, which is often the case with EU rules, support (or opposition) are likely to 
be weak. With only one side of the argument engaged the policy process appears apolitical.

Furthermore, even where there are engaged contending interests, the character of regulatory politics works against confrontation. Regulations tend to be highly technical and require specialist knowledge, which means that ideas and persuasion are the currencies of influence (Berry 1984). Influence comes from being a reliable and informative interlocutor that can provide expertise and deliver on commitments. The centrality of regulation in EU policy activity, therefore, contributes strongly to the apolitical character of EU interest group competition.

The second institutional legacy that works against confrontational politics is the diplomatic tradition upon which the EU is based. This has two implications for the character of interest group politics. The first is that there is a culture of consensual decision-making that emanates from the Council of Ministers on down (Wallace 2000). In diplomatic negotiations it is important to make sure that everybody is happy and efforts are made to avoid creating clear cut winners and losers. This tendency is reinforced by the highly institutionalized character of iterated cooperation in the EU (Keohane 1986; Hayes-Renshaw and Wallace 1997). Moreover, there is no 'EU government' and there is very little majoritarian politics.

The second implication is the relative weakness of the European Parliament. Even though the Parliament's powers have been repeatedly augmented, they still fall far short of those of the US Congress. Most importantly, the European Parliament does not have the authority to initiate legislation, as does the Congress. Differences in the locus of political authority between the EU and the US affect not only where interest groups focus their attention, but also the tools at their disposal for seeking to influence policy. While interest groups in the EU must rely almost entirely on persuasion and expertise, interest groups in the US have more coercive sources of influence. The most frequently used strategies in the US, often used in combination, are lobbying, establishing access to key decision makers, using the courts, going public and using electoral politics (Grossman and Helpman 2001; Lowi and Ginsberg 2000). Only the first two of these strategies are really available to EU interest groups, though the third might become a more viable option in the future. Thus the strategies available to EU interest groups are the less overtly political ones.

Thus the most striking difference between interest group politics in the EU and US concerns the impact of public opinion and electoral politics on the policy process. The importance of Congress in rule-making means that both money and voters are sources of influence in US interest group politics in ways that they are not in the EU. The much weaker party structure in the US compared to western Europe means that individual candidates must raise most of the funds for their campaigns. Further, the high cost of running for office means that Congresspeople need to be almost perpetually fundraising. Consequently, interest groups with money are at least likely to get a hearing. As noted above, the Commission plays a pivotal role in the policy process, but it is not elected. Candidates for the European Parliament are supported by party funds and so there is no direct connection between contributors and legislators. These differences, combined with the Commission's dependence on external sources of expertise, explain why ideas, not money, are the currency of influence in the EU.

But money is only a means to an end-(re-)election. Consequently, US interest groups that are able to mobilize large numbers of voters, particularly in key constituencies, have enhanced clout. Such mobilization-so-called 'grass roots' or 'outsider' lobbying-can signal to legislators the electoral consequences of their actions (Goldstein 1999). The AARP, for instance, has 35 million members, 
including many members in the finely balanced state of Florida. It is a common (and increasingly so) strategy for US interest groups to mobilize their members to write to Congresspeople supporting a particular line of policy (Goldstein 1999). The unavailability in the EU of such tools of influence tends to make interest group politics less overtly political in the EU than in the US.

The third institutional legacy that reinforces the relatively apolitical character of EU interest group politics is the lack of a tradition of pluralist politics in many of the member-states (Schmidt 1999). In corporatist countries such as Austria and Germany, consensus among supposedly rival interest groups is the norm. In the Scandinavian countries interest groups are thoroughly consulted, but are very much part of insider politics, and public disagreements are rare. A number of other member-states, such as France, have statist polities, in which interest groups have little say in the policy process (Schmidt 1999). As EU associations are usually associations of national associations, these national traditions influence the behaviour of EU interest groups.

The fourth institutional legacy is a product of the place of interest groups in the EU's legal system. The legal process by definition is conflictual, not consensual. Litigation is used much more extensively by interest groups in the US, which may reflect the more confrontational nature of politics, but also reflects the important institutional legacies of the American court system. Analogous opportunities for EU interest groups to use litigation to advance their agendas are much more limited.

To start with, the Commission relatively rarely takes the kinds of decisions that might be challenged by firms on procedural grounds. Challenges to the Commission's decisions regarding anti-dumping duties and in competition policy, especially vetting mergers, are the exceptions rather than the norm. Firms are much more likely to seek to challenge national rules for not being compatible with EU rules.

Public interest groups in the US have also used the courts to push change-sometimes of a profound nature (Baumgartner 1996). Perhaps the most striking example is the National Association for the Advancement of Coloured People's (NAACP) role in Brown $v$ Board of Education of Topeka, which opened the door to desegregation. Given the EU's treaties' emphasis on economic issues, even if public interest groups gain standing they will not be able to press such sweeping changes through the courts. ${ }^{3}$ The most striking exception to this is with regard to gender equality, which has been enhanced in a number of member-states, including the UK, as the result of legal action invoking the EU's treaties (Caporasso and Jupille 2001). Should the Constitutional Treaty be ratified, additional fundamental human rights will be incorporated into EU law. In the meantime, public interest groups, acting (in present circumstances) through affected individuals, can try to affect policy change through legal action, in limited but important policy areas, such as the environment. As outlined earlier, should groups be able to be litigants EU groups may begin using the courts in ways more similar to their US counterparts.

\section{Interest groups in the transatlantic relationship}

Given the differences in how US and EU interest groups are organized, in their relationships with their respective governments, and in the character of their politics, it is not a surprise that the transatlantic dialogues between interest groups in particular areas-business, labour, consumers and the environment-have, to differing degrees, struggled.

\footnotetext{
${ }^{3}$ Many of the rights that US public interest groups have successfully engaged through the courts in Europe fall under the European Convention on Human Rights, which is currently entirely separate from the EU.
} 
Even the Transatlantic Business Dialogue (TABD), which had long been regarded as a great success story, has recently had problems, though these are more external than internal. The TABD began in 1995 as a joint government initiative to provide a forum for transatlantic businesses to resolve their differences and to present joint policy proposals to the EU and US administrations. Like the ERT, its members are CEOs of firms, not firms themselves. Not surprisingly given their interests, much of the memberships of the ERT and AMCHAM-EU are engaged in the TABD. As the TABD is a direct member association engaging relatively similar members, it has not had the pronounced cultural clashes between EU and US members that have complicated the other dialogues (see below).

While the firm-engagement aspect of the process has worked quite well, there have been problems in getting business proposals converted into political action. As the TABD is 'results driven' (Coen and Grant 2001: 43), this has raised doubts about the long-term viability of the exercise. The 28 April 2003 'renewed commitment' by the Bush Administration and the European Commission to the $T A B D$ is an attempt to redress the problem posed by the limited impact of the TABD on policy to date.

The problems besetting the other dialogues are internal and more profound, and the political support has been weaker. The Transatlantic Environmental Dialogue (TAED) and the Transatlantic Labour Dialogue (TALD) and the Transatlantic Consumer Dialogue (TACD) all started in response to the TABD, and all three started as initiatives of the interest groups themselves, although they subsequently, in many cases reluctantly, received government support.

The TAED was initially funded by a foundation, but was subsequently funded by the EU and US, though only after US environmental groups' reservations about accepting government money were overcome. The TAED also wrestled (ultimately successfully) with whether non-member organisations should be allowed to be full members and whether government officials should be able to participate, with the EU groups in favour of both and the US groups more reluctant (Bignami and Charnovitz 2001). Although the TAED was ultimately able to overcome its internal differences, it has since been wound up following the US government's withdrawal of funding.

The TACD, which is still active, has also experienced cultural differences related to the different relationships among consumer groups in the EU and US and between consumer groups and their respective governments. The European consumer groups were already used to cooperating with each other and with the Commission (Young 1998). The consumer movement on the US, however, was less used to cooperating, was used to an arm's-length relationship with government, and did not traditionally engage on international trade issues (Bignami and Charnovitz 2001). In addition, like US environmental groups, the US consumer groups distrusted the dialogue because it was government funded, and some, such as the Consumers' Union, are barred by their charters from accepting government money (Bignami and Charnovitz 2001). The US consumer groups also experienced more profound ideological differences than their EU counterparts, with some fearing that the TACD was simply a vehicle for legitimising trade liberalisation, rather than as a means of incorporating non-trade interests (Bignami and Charnovitz, 2001). The TACD has largely managed to overcome these internal differences and has been remarkably successful at agreeing robust common positions (Bignami and Charnovitz 2001). It has also played an important role in educating consumer groups about concerns on the other side of the Atlantic, as the mobilization of US groups on the issue of genetically modified food after the first TACD meeting 
illustrates (Young 2003). The responsiveness of government, particularly on the US side, however, has proved disappointing (Bignami and Charnovitz 2001).

The TALD had fewer internal organisational problems than either the TACD or TAED. It was initiated as a joint project of the US and EU peak labour associationsthe AFL-CIO and European Trade Union Confederation (ETUC), so questions of membership and coordination were rendered moot. Expectations were low, however, and neither organisation seemed to take the dialogue very seriously (Knauss and Trubek 2001). There appear to be several reasons for this, including the nature of labour markets, the characters of the members and the focus of the transatlantic agenda (Knauss and Trubek 2001). First, there is not much in the way of labour issues to discuss, as labour markets and their associated regulations are local or national. Second, neither association has much control over its members and they are themselves very different. The ETUC is a confederation of national umbrella associations, many of which are used to engaging in collective bargaining at the national level. The AFL-CIO is a national umbrella association, which is used to being an 'outsider' group trying to get the government to listen to the voice of labour. Third, the transatlantic agenda is about market integration and there is little space in the formal agenda for labour issues. Not surprisingly, the TALD has been wound up.

\section{Conclusion}

Simply by bringing together 25 member-states, the EU engages a greater variety of interests than does any individual member-state, and so fosters the Madisonian principle of pluralism. Furthermore, as a pragmatic project to improve the quality of policies, the EU has tended to be more open to more interests than the governments of at least most of the member-states.

The EU system of interest representation is not, however, nearly as pluralist as the US. It retains some more European features. There are many fewer interests engaged in the EU and the dominance of producer over consumer interests can be greater, reflecting the economic focus of European integration. In addition, the EU system is more elite and institutionalized in nature, more remote from citizen mobilization and participation, and much more likely to formalize consultative arrangements with selected interest groups. The EU system of interest representation, therefore, seems to lie somewhere between the extremes of US pluralism and European corporatism and statism.

Some recent developments suggest the possibility of greater pluralism within the EU. The broadening of the EU policy agenda has engaged more numerous and more diverse interests in the EU policy process. The implementation of the Governance White Paper, which would be reinforced by the ratification of the Constitutional Treaty, commits the EU's institutions to consult with organized civil society. This will likely strengthen the hand of public interest groups, which have tended to be more excluded from the policy process, thus diluting further the dominance of producer interests. In addition, if interest groups do receive standing under EU law and are bolstered by the incorporation of the Charter of Fundamental Rights into the Constitutional Treaty, so the door will be opened for public interest groups to pursue more sweeping policy change through litigation.

There are, however, important limits to the extension of democracy through increasing interest group participation. One is that the regulatory nature of EU policy-making tends to engage only relatively few, narrow interests. Although increasing consultation with specific groups on specific rules may enhance the legitimacy of particular pieces of legislation, it will not make many strides towards reducing the overall perception of the EU's democratic deficit. Further, most 
interest groups operating at the EU level are associations of national associations which creates problems of effectiveness and accountability within the very institutions the EU is looking to bolster its legitimacy.

Perhaps the most striking feature of the EU's pluralism is how consensual it is. This apparent blandness may contribute to the perception of the EU as a remote and secretive institution; disagreements only emerge behind closed doors. This peculiarity, we have argued, is also nonetheless easily comprehensible as a product of institutional legacies: the disguised redistributive qualities of regulations; the tradition of diplomatic decision-making and the accompanying weakness of electoral politics; different national traditions of interest group politics, many of which find competition alien; and the limited scope for EU interest groups to use the confrontational tool of litigation to advance their policy objectives.

Irrespective of this veneer of consensus, the EU's interest group politics are undergoing profound change, particularly in the direction of extending democracy. These changes have been encouraged by the institutional legacy of the single European market and its accompanying 'flanking' policies, as well as by attempts to broaden consultation in the policy process. There are, however, important institutional legacies that severely limit the extent to which bolstering interest group participation will redress the EU's democratic deficit. Interest group politics may be a necessary, but are not a sufficient, condition for democratic legitimacy in the evolving European polity. 


\section{References}

Aspinwall, M. and Greenwood, J. (1998), 'Conceptualising Collective Action in the European Union,' in J. Greenwood and M. Aspinwall (eds), Collective Action in the European Union (London: Routledge), pp. 1-30.

Baumgartner, F. R. (1996), 'Public interest Groups in France and the United States,' Governance, 9/1, pp. 1-22.

Baumgartner, F. R. and Jones, B (1993) Agendas and Instability in American Politics (Chicago: University of Chicago Press).

Berry, J. M. (1984), The Interest Group Society (Boston: Little, Brown and Company).

Bignami, F. and Charnovitz, S. (2001), 'Transatlantic Civil Society Dialogues,' in M. A. Pollack and G. C. Shaffer (eds), Transatlantic Governance in the Global Economy (Lanham, MD: Rowman \& Littlefield), pp. 255-84.

Caporasso, J. and Jupille, J. (2001), 'The Europeanization of Gender Equality Policy and Domestic Structural Change,' in M. G. Cowles, J. Caporaso, T. Risse (eds), Transforming Europe: Europeanization and Domestic Change (Ithaca, NY: Cornell University Press), pp. 21-43.

Coen, D (1997) 'The Evolution of the Large Firm as a Political Actor in the European Union,' Journal of European Public Policy, 4, 1: 91-108

Coen, D. and Grant, W. (2001), 'Corporate Political Strategy and Global Policy: A Case Study of the Transatlantic Business Dialogue,' European Business Journal, 13/1, pp. 37-44.

Coleman, W. D. and Montpetit, E. (2000), 'Multitiered Systems and the Organization of Business Interests,' in J. Greenwood and H. Jacek (eds), Organized Business and the New Global Order (London: Macmillan).

Commission (2000), 'The Commission and Non-Governmental Organisations: Building a Stronger Partnership,' COM(2000) 11 final, 18 January 2000

Commission (2001), 'European Governance: A White Paper,' COM(2001) 428 final.

Cowles, M. G. (1997), 'Organizing Industrial Coalitions: A Challenge for the Future? in H. Wallace and A. R. Young (eds), Participation and PolicyMaking in the European Union (Oxford: Clarendon Press), 116-40.

Cowles. M. G. (2001), 'The Transatlantic Business Dialogue and Domestic Business-Government Relations,' in M. G. Cowles, J. Caporaso, T. Risse (eds), Transforming Europe: Europeanization and Domestic Change (Ithaca, NY: Cornell University Press), pp. 159-79.

Davis, J. (2003) 'This is My Life: Tony Long,' E!Sharp, April, pp 64-68.

Goehring, R (2002) 'Interest Representation and Legitimacy in the European Union: The New Quest for Civil Society Formation,' in Warleigh, A and Fairbrass J (2002) Influence and Interests in the EU: The New Politics of Persuasion and Advocacy (London: Europa), Chapter 7, pp 118-137 
Goldstein, K. M. (1999), Interest Groups, Lobbying and Participation in America (Cambridge: Cambridge University Press).

Grande, E. (1996) 'The State and Interest Groups in a Framework of Multi-Level Decision Making: the case of the European Union,' Journal of European Public Policy, 3: 3, September, pp 318-38.

Greenwood, J. (1997) Representing Interests in the European Union (Basingstoke: Macmillan)

Greenwood, J. (2002) Inside the EU Business Associations (Basingstoke: Palgrave)

Greenwood, J (2003) Interest Representation in the European Union (Basingstoke: Palgrave Macmillan)

Greenwood, J., Grote J. and Ronit K. (1992) Organized Interests and the European Community (London: Sage)

Grossman, G. M. and Helpman, E. (2001), Special Interest Politics (Cambridge, MA: MIT Press).

Harlow, C. and Rawlings, R. (1992), Pressure Through Law (London: Routledge).

Hayes-Renshaw, F. and Wallace, H. (1997), The Council of Ministers of the European Union (London: Macmillan).

Helfferich, B. and Kolb, F. (2001) 'Multilevel Action Coordination in European Contentious Politics: The Case of the European Women's Lobby,' in D. Imig and S. Tarrow (eds), Contentious Europeans: Protest and Politics in an Integrating Europe (Lanham, MD: Rowman and Littlefield)

Keohane, R. O. (1986), 'Reciprocity in International Relations,' International Organization, 40/1, 1-27.

Knauss, J. and Trubek, D. (2001), 'The Transatlantic Labor Dialogue: Minimal Action in a Weak Structure, in M. A. Pollack and G. C. Shaffer (eds), Transatlantic Governance in the Global Economy (Lanham, MD: Rowman \& Littlefield), pp. 235-54.

Lowi, T. (1964), 'American Business, Public Policy, Case Studies and Political Theory,' World Politics, 16/4, pp. 677-715.

Lowi, T. J. and Ginsberg, B. (2000), American Government: Freedom and Power, Brief Sixth Edition (New York: W. W. Norton).

Martin, A. and Ross, G. (2001) 'Trade Union Organizing at the European Level,' in D Imig and S Tarrow (eds.) Contentious Europeans, Lanham (MD) Rowman and Littlefield, pp 53-76.

Reid, A (2003) 'EU Competition Law and Trade Associations,' in J Greenwood (ed.) The Challenge of Change in EU Business Associations (Basingstoke: Palgrave Macmillan), pp 74-92.

Schmidt, V (1999) 'National Patterns of Governance Under Siege: the impact of European integration,' in Kohler-Koch, B and Eising, R (eds.) The 
Transformation of Governance in the European Union (London: Routledge), pp 155-172.

Schmitter, P. C. and Streeck, W. (1981), 'The Organization of Business Interests: A Research Design to Study the Associative Action of Business in the Advanced Industrial Societies of Western Europe,' Internationales Institut für Management und Verwaltung, Wissenschaftszentrum Berlin, Arbeitsmarktpolitik, No. 13.

Streeck, W. and Schmitter, P. C. (1991), 'From National Corporatism to Transnational Pluralism: Organized Interests in the Single European Market,' Politics and Society, 19:2, 133-64.

Thomas, C. S. (2001) (ed.), Political Parties and Interest Groups: Shaping Democratic Governance (Boulder, CO: Lynne Rienner).

Wallace, H. (2000), 'The Policy Process,' in H. Wallace and W. Wallace (eds), Policy-Making in the European Union, $4^{\text {th }}$ edition (Oxford: Oxford University Press), pp. 39-64.

Warleigh, A. (2001) 'Europeanizing Civil Society: NGOs as Agents of Political Socialization,' Journal of Common Market Studies, 39:4, pp 619-639.

Webster, R. (1998), 'Environmental Collective Action: Stable Patterns of Cooperation and Issue Alliances at the European Level,' in J. Greenwood and M. Aspinwall (eds), Collective Action in the European Union: Interests and the New Associability (London: Routledge), 176-95.

Wilson, J. Q. (1980), The Politics of Regulation (New York: Basic Books)

Young, A. R. (1998), 'European Consumer Groups: Multiple Levels of Governance and Multiple Logics of Collective Action,' in J. Greenwood and M. Aspinwall (eds), Collective Action in the European Union: Interests and the New Associability (London: Routledge), 149-75.

Young, A. R and Wallace, H. (2000a), 'The Single Market: A New Approach to Policy,' in H. Wallace and W. Wallace (eds.), The Politics of Policy-Making in the European Union, $4^{\text {th }}$ edition, Oxford University Press.

Young, A. R. and Wallace, H. (2000b), The Politics of Regulation in an Enlarging European Union, Manchester University Press.

Young, A. R. (2003), 'Political Transfer and Trading Up? Transatlantic Trade in Genetically Modified Food and US Policies,' World Politics, 55:4, pp.457-84. 